\title{
CORRECTION
}

\section{Correction to: Experimental study with gentamicin impregnated plaster pellets}

\section{Etude expérimentale de languettes de plâtre imprégnées de Gentamicine ${ }^{\circledast}$}

Jaime Jose Morales de Cano ${ }^{1,4} \cdot$ A. Fernandez Sabate ${ }^{1} \cdot$ J. L. Bombi ${ }^{2} \cdot$ J. Cabo $^{1} \cdot$ N. Basi ${ }^{3}$

Published online: 28 May 2021

๑ Springer-Verlag France SAS, part of Springer Nature 2021

\section{Correction to: Orthop Traumatol (1994) 4: 93-95 https://doi.org/10.1007/BF01803642}

The original version of this article unfortunately contained a mistake. The family name of author "Jaime Jose Morales de Cano" was incorrect.

The correct given name and family name should be:

Given name: Jaime Jose.
Family name: Morales de Cano.

Publisher's Note Springer Nature remains neutral with regard to jurisdictional claims in published maps and institutional affiliations.

The original article can be found online at https://doi.org/10.1007/ BF01803642.

Jaime Jose Morales de Cano

15449jmc@comb.cat

1 Service of Orthopedics Surgery and Traumatology, Ciudad Sanitaria y Universitaria de Bellvitge, Hospitalet de

Llobregat, Barcelona, Spain

2 Department of Pathology, Hospital Clinico y Provincial, Barcelona, Spain

3 Centro de Investigación y Desarrollo Aplieado, Sta. Perpetua de la Moguda, Barcelona, Spain

4 Balmes $3951^{\circ} 2 \mathrm{a}, 08022$ Barcelona, Spain 